\title{
Determination of Fire and Burning Properties of Spruce Wood
}

\section{Određivanje zapaljivosti i obilježja gorenja drva smreke}

\author{
Preliminary paper • Prethodno priopćenje \\ Received-prispjelo: 28. 12. 2011. \\ Accepted-prihvaćeno: 6. 9. 2012. \\ UDK: $630 * 812.5 ; 674.032 .475 .54$ \\ doi:10.5552/drind.2012.1141
}

\begin{abstract}
This paper deals with the determination of selected fire properties of spruce wood. It describes the general characteristics of spruce wood, microscopic and macroscopic features. Broad application of this material requires the assessment of its properties regarding the fire aspects, being a cause of fire in forests or due to frequent occurrence of wildland fires in the Slovak territory, and being a flammable material used in building industry, furniture industry, etc. This paper analyses the following fire properties: flash-ignition temperature, spontaneousignition temperature, mass burning rate, ignitability of material exposed to a small open flame.
\end{abstract}

Keywords: spruce, fire properties, flash-ignition temperature, spontaneous-ignition temperature, burning rate, ignitability

SAŽETAK - Tema rada je određivanje svojstava zapaljivosti i gorenja drva smreke. Opisuju se opća te mikroskopska i makroskopska obilježja smrekovine. Zbog široke primjene smrekovine vrlo je važna procjena njezinih svojstava zapaljivosti, posebno zato što su u smrekovim šumama na slovačkom području česti požari a smrekovo se drvo često koristi u graditeljstvu, industriji namještaja i sl. Svojstva zapaljivosti i gorenja analizirana u ovom radu jesu flash temperatura zapaljenja, temperatura spontanog zapaljenja, brzina gorenja te zapaljivost materijala izloženoga slaboj otvorenoj vatri.

Ključne riječi: smreka, svojstva zapaljivosti, flash temperatura zapaljenja, temperatura spontanog zapaljenja, brzina gorenja, zapaljivost

\section{INTRODUCTION \\ 1. UVOD}

Wood is a natural organic material whose extraction, processing and application plays an important role nowadays. Therefore, it is necessary to accept the fact that wood in any form (raw material, semi-finished product, and end product) cannot be exposed to higher temperatures, and this is considered to be an important negative feature, especially when wood is used as a construction material.
Many authors, e.g. Kačíková (2006) and Osvald (2007), deal in their papers with both influence of wood properties on flammability and external conditions affecting thermal degradation of wood.

Based on the flash-ignition temperature and spontaneous-ignition temperature, according to the ISO 871:2006, the relative comparison of a material resistance against ignition can be determined.

Karlsson and Quintere (2000) stated that for reaching the flash-ignition temperature, the temperature in

\footnotetext{
${ }^{1}$ Author is assistant at Department of Fire Protection, Faculty of Wood Sciences and Technology, Technical University in Zvolen, Zvolen, Slovakia.

Autor je asistent Odjela za zaštitu od požara, Fakultet znanosti o drvu i tehnologije, Tehničko sveučilište u Zvolenu, Zvolen, Slovačka.
} 
the fire compartment should reach 500 to $600{ }^{\circ} \mathrm{C}$ or the radiant flux on the floor should be 15 to $20 \mathrm{~kW} \cdot \mathrm{m}^{-2}$. The temperatures referred to above are significantly higher than the spontaneous-ignition temperatures of most lignocellulose materials.

The basic fire performance properties of wood, from the point of construction, especially wooden constructions, were analysed by Delichatsios et al. (2003). They argued that by using the modified conical calorimeter with the heat flux between 15 and $50 \mathrm{~kW} \cdot \mathrm{m}^{-2}$, the other fire characteristics could be derived such as conductivity, thermal capacity, spontaneous-ignition temperature, latent heat, gross heat of combustion, etc. The conclusion was that the heat flux of $18 \mathrm{~kW} \cdot \mathrm{m}^{-2}$ becomes critical for raw wood.

This paper introduced an assessment of wood properties related to fire performance of spruce wood. It deals with the description of the general characteristics of spruce wood, microscopic and macroscopic features. Furthermore, it focuses on the description of the procedure for determining the selected fire characteristics, especially the flash-ignition temperature, spontaneousignition temperature, mass burning rate, and ignitability of material exposed to a small open flame.

Spruce wood is the most widely used wood species in Slovakia (excellent technical properties, handling properties, and large domestic sources). It is the most important wood for processing; it is also used as a construction and auxiliary material in building industry and maintenance, in package making industry, in mining, as a transport construction material, in engineering, in furniture manufacture, plywood, fibrous boards, chipboards, etc. Spruce wood is also very valuable as a highly resonant wood (Korytárová and Osvald, 2000; Požgaj et al., 1997).

Taking into account the wide application of this material, it is important to assess it not only from its quality, functionality and utilization aspect, but also from the point of view of its fire performance.

Spruce wood is also used in biomass production. During its combustion, it is important to know all the physical and chemical parameters of combusted materials as well as to study nitrogen oxides that represent the most important toxicological fire products. Nowadays, the concentration can be estimated relatively accurately for the industrial combustion conditions. In industrial combustion, these conditions are set to reach maximum combustion efficiency meeting the emission limits (Martinka et al., 2011).

\section{MATERIAL AND METHODS}

\section{MATERIJAL I METODE}

\subsection{Characteristics of the studied wood: Norway} Spruce (Picea abies L. Karst)

2.1. Obilježja istraživanog drva: norveška smreka (Picea abies L. Karst)

\subsubsection{Microscopic features}

\subsubsection{Mikroskopska obilježja}

The wood is without any core, it is fresh and with well a visible zone of ripe wood. Its colour is white or yellowish white, and it turns into yellow under light.
The annual rings are clearly visible, narrow summer wood gradually changes into broad spring wood. Resin channels are small and scattered, visible by the eye only on longitudinal well processed cutting profiles as gentle longitudinal darker ruptures. Fresh wood smells like resin. Rays can be visible by the eye. The wood is soft, well splittable and lightweight $\left(\rho=430 \mathrm{~kg} \cdot \mathrm{m}^{-3}\right)$ (Korytárová and Osvald, 2000).

\subsubsection{Macroscopic features}

\subsubsection{Makroskopska obilježja}

The basic construction elements of spruce wood are tracheids - vessels that represent up to $94.5 \ldots 95.3 \ldots 96.5 \%$ of the whole wood volume. They are $1.7 \ldots 2.9 \ldots 3.7 \mathrm{~mm}$ long. Rays are dominantly of one layer, consisting of parenchymatous cells; on their circumference, transverse tracheids are located with smooth or weakly waved walls with paired dots. The yield of rays is $4.4 \ldots 4.7 \ldots 5.5 \%$. Spruce wood is characterized by the presence of resin channels well visible on transverse cutting profile - vertical channels. Horizontal channels can be seen on tangential cutting profile. About 30 to 100 vertical resin channels can be found on $1 \mathrm{~cm}^{2}$ of the transverse cutting profile area of spruce wood. They are mostly present in summer wood and can be seen by the eye as gentle grooves or significant lines on longitudinal cutting profiles. Spruce wood has very narrow resin channels $(0.09 \mathrm{~mm})$ and the yield share is $0.2 \%$. The resin has a protective function for the tree (when the tree is mechanically or biologically damaged) and an impregnation function - it increases the wood resistance against fungi (Korytárová and Osvald, 2000; Požgaj et al., 1997).

Physical, mechanical and fire and burning properties of wood are described in many publications, for example by Rowell (2005); the characteristics of spruce wood are introduced in the catalogue of fire and technical properties of materials (The catalogue of fire and burning behaviour properties of materials, 1984). The physical, mechanical and fire and burning properties of spruce wood are presented in Table 1.

\subsection{Determination of flash-ignition temperature and spontaneous-ignition temperature}

2.2. Određivanje flash temperature paljenja i temperature spontanog zapaljenja

Testing was carried out in accordance with the standard STN ISO 871: 1999. The basic terminology is as follows:

- flash-ignition temperature (FIT) is the minimum temperature at which, under specified test conditions, sufficient flammable gases are emitted to ignite momentarily by application of a pilot flame;

- spontaneous-ignition temperature (SIT) is the minimum temperature at which, under specified test conditions, ignition is obtained by heating in the absence of any additional flame source.

The standard is based on the principle of heating a material in the heating chamber of a hot air furnace (see Figure 1) using various temperatures.

\section{Flash-ignition temperature (FIT)}

The electric power supplied to the heating coil is adjusted until the air temperature remains constant at the 
Table 1 Physical, mechanical and fire and burning properties of spruce wood (Source: The catalogue of fire and burning behaviour properties of materials. Coniferous wood X)

Tablica 1. Fizikalna i mehanička svojstva te svojstva zapaljivosti i gorenja drva smreke (Izvor: The catalogue of fire and burning behaviour properties of materials. Coniferous wood X)

\begin{tabular}{|l|c|}
\hline $\begin{array}{l}\text { Physical, mechanical and fire and burning properties of spruce wood } \\
\text { Fizikalna i mehanička svojstva te svojstva zapaljivosti i gorenja drva }\end{array}$ & $\begin{array}{c}\text { Value valid for 15 \% wood } \\
\text { humidity / Vrijednosti za } \\
\text { drvo sa sadržajem vode 15\% }\end{array}$ \\
\hline Density / gustoća & $430 \mathrm{~kg} \cdot \mathrm{m}^{-3}$ \\
\hline Compressive strength in fibre direction / tlačna čvrstoća u smjeru vlakanaca & $43 \mathrm{MPa}$ \\
\hline Bending strength / čvrstoća na savijanje & $66 \mathrm{MPa}$ \\
\hline Shearing strength / smicajna čvrstoća & $6.7 \mathrm{MPa}$ \\
\hline Elasticity modulus in tension / modul elastičnosti & $11000 \mathrm{MPa}$ \\
\hline Impact toughness / žilavost & $5 \mathrm{~J} \cdot \mathrm{cm}^{-2}$ \\
\hline Hardness (Brinell) / tvrdoća (prema Brinellu) & $12 \mathrm{~N} \cdot \mathrm{mm}^{-2}$ \\
\hline Flash-ignition temperature [STN 64 0149] / flash temperatura paljenja [STN 64 0149] & $350-360^{\circ} \mathrm{C}$ \\
\hline $\begin{array}{l}\text { Spontaneous-ignition temperature [STN 64 0149] } \\
\text { temperatura spontanog paljenja [STN 64 0149] }\end{array}$ & $390-400^{\circ} \mathrm{C}$ \\
\hline Oxygen index [STN 64 0756] / indeks kisika [STN 64 0756] & $25.0 \% \mathrm{obj}^{\circ} \mathrm{O}_{2}$ \\
\hline Gross heat of combustion [STN 44 1352] / bruto toplina izgaranja [STN 44 1352] & $19.9 \mathrm{MJ} \cdot \mathrm{kg}^{-1}$ \\
\hline Optical density of smoke / optička gustoća dima & $7.3 \mathrm{~m}^{2} \cdot \mathrm{kg}^{-1}$ \\
\hline Mass burning rate / brzina gorenja & $0.056 \mathrm{~kg} \cdot \mathrm{m}^{-2}$ \\
\hline
\end{tabular}

desired initial test temperature. The pan with the specimen is inserted into the furnace. The timer is activated, then the pilot flame is ignited and evidence of a flash or mild explosion of combustible gases, which may be followed by continuous burning of the specimen, is observed. Also flame-burning or glowing combustion can occur in case of sudden increasing of the temperature $T_{1}$ compared with the temperature $T_{2}$. If in 10 minute interval, the flash ignition has occurred, the temperature $T_{2}$ is lowered or raised by $50{ }^{\circ} \mathrm{C}$ and the test is repeated with a fresh specimen. If the range in which the flash-ignition temperature is reached has been determined, tests begin at the temperature lower by $10{ }^{\circ} \mathrm{C}$ than the highest temperature and continue by lowering the temperature by another $10^{\circ} \mathrm{C}$ until the temperature at which no ignition occurs in a 10 min interval is reached. The lowest air temperature $T_{2}$, at which a flash ignition was observed during the 10 min interval, is considered as the flashignition temperature (STN ISO 871:1999).

\section{Spontaneous-ignition temperature (SIT)}

The same procedure is carried out as for FIT but without the pilot flame. The lowest air temperature $T_{2}$ at which flaming or glowing combustion of the specimen is observed during the $10 \mathrm{~min}$ interval is considered as the spontaneous-ignition temperature.

To determine the flash-ignition temperature and spontaneous-ignition temperature, the spruce wood specimens were prepared so as to meet the requirements for sample specimen mass of $3.0 \mathrm{~g} \pm 0.2 \mathrm{~g}$ (according to the standard STN ISO 871), while for the comparative purposes these specimens were prepared from the tree trunk, branch and root (the branch and root thickness was lower than $5 \mathrm{~mm}$ ).

\subsection{Determination of the mass burning rate} 2.3. Određivanje brzine gorenja (smanjenja mase)

Testing apparatus schematically illustrated in Figure 2 is used for model burning tests. This apparatus

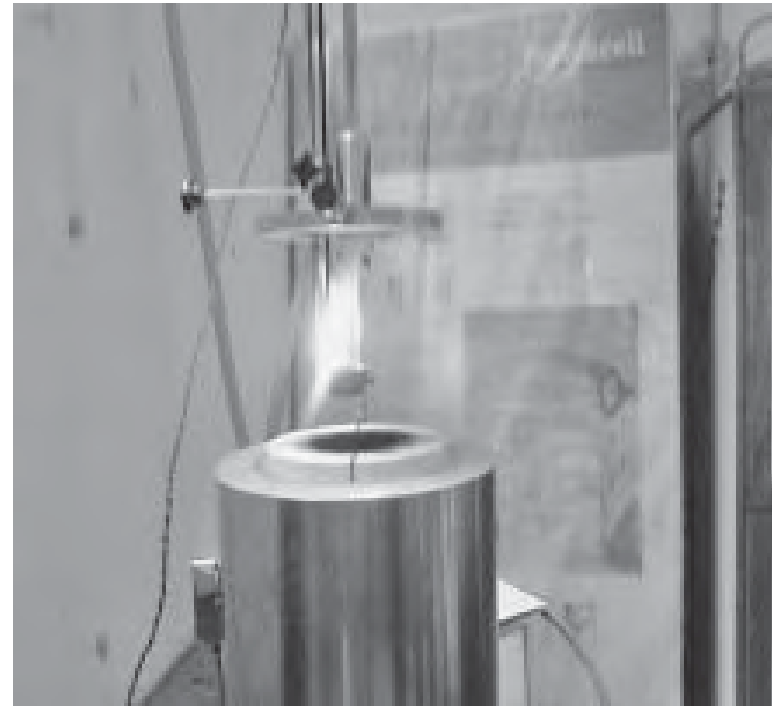

Figure 1 Photo of the apparatus for STN ISO 871 Slika 1. Uređaj za STN ISO 871

consists of the electronic weight (4) with the accuracy of two decimal places, weight protection unit (3), e metal holder (6) for placing testing specimen (5), metal loading frame (2) for placing radiant heat source and infrared thermal heater (1) with the input of $1000 \mathrm{~W}$, heater surface temperature of $652.7^{\circ} \mathrm{C}$, maximum wavelength of $3.11 \mu \mathrm{m}$, and radiation intensity of 3.055 $\mathrm{W} \cdot \mathrm{cm}^{-2}$ (Zat'ko, 1993).

Testing procedure - the experiment is based on exposing the testing specimens to the thermal infrared heater (radiant heat source) in 10 minute intervals at the distance of $30(35,40,45$ and $50 \mathrm{~mm})$ from the radiating heater surface. During the test, the mass loss is recorded in regular 10 second intervals.

To determine the burning rate in the specified time interval, the absolute burning rate $v_{\mathrm{a}}$ is calculated according to the relation (Osvald and Osvaldová, 2003): 


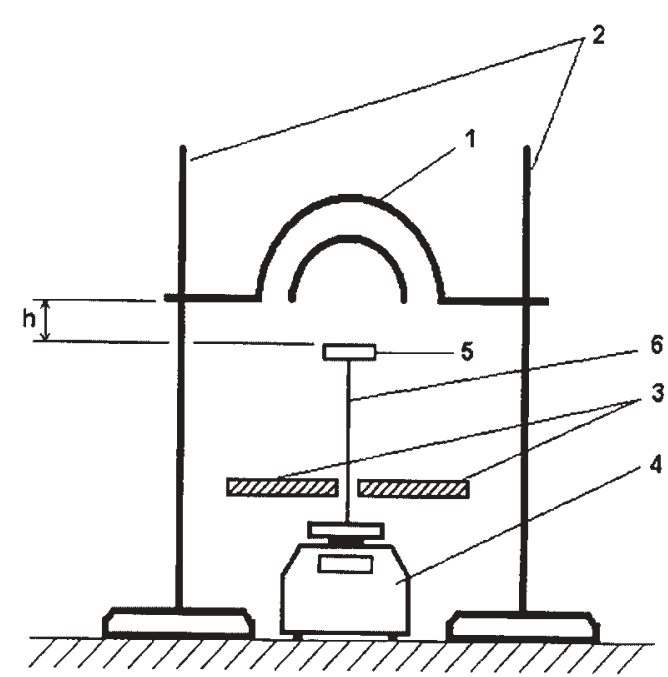

Figure 2 Testing apparatus for the determination of mass burning rate

Slika 2. Uređaj za određivanje brzine gorenja

$$
v_{a}=\frac{m(\tau)-m(\tau+\Delta \tau)}{\Delta \tau}
$$

Where:

$v_{\mathrm{a}}$ - absolute burning rate, $\mathrm{g} \cdot \mathrm{s}^{-1} /$ apsolutni brzina gore$n j a, g \cdot s^{-1}$

$m(\tau)$ - specimen mass in the time $\tau$, g / gubitak mase uzorka $u$ vremenu $\tau$, $g$

$m(\tau+\Delta \tau)-$ specimen mass in the time $\tau+\Delta \tau, \mathrm{g} /$ gubitak mase uzorka $u$ vremenu $\tau+\Delta \tau, g$

$\Delta \tau$-time interval in which mass values are recorded, $\mathrm{s}$ / vremenski razmak u kojemu se bilježi vrijednost mase, $s$.

\subsection{Determination of ignitability}

\subsection{Određivanje zapaljivosti}

The testing procedure is determined according to the standard STN EN 11925-2: 2004. This test determines ignitability of a product when exposed to a small flame source. The test is used with different classes of reaction-to-fire $\mathrm{B}, \mathrm{C}, \mathrm{D}, \mathrm{E}$ (construction products except floor coverings and thermal insulating products for linear ducts), $\mathrm{B}_{\mathrm{fl}}, \mathrm{C}_{\mathrm{fl}}, \mathrm{D}_{\mathrm{fl}}, \mathrm{E}_{\mathrm{fl}}$ (floor coverings), and $B_{L}, C_{L}, D_{L}, E_{L}$ (thermal insulating products for linear ducts).

The testing apparatus consists of a combustion chamber (see Figure 3) made of metal sheet and rustproof steel, equipped with thermal resistant glass doors, enabling access and observation from the front side and a lateral side.

The test specimen is clamped in the specimen holder so that one end and both sides are covered by the holder frames and the exposed end is $30 \mathrm{~mm}$ from the end of the frame.

The distance between the burner and the specimen is checked by the relevant spacer. For this purpose two kinds of distance spacers can be used. One is used to measure the distance between the burner and specimen on the specimen front principal surface and the other on the specimen lateral side surface.

The burner is lighted in the vertical position to stabilize the flame. A flame height of $20 \mathrm{~mm}$ is adjusted

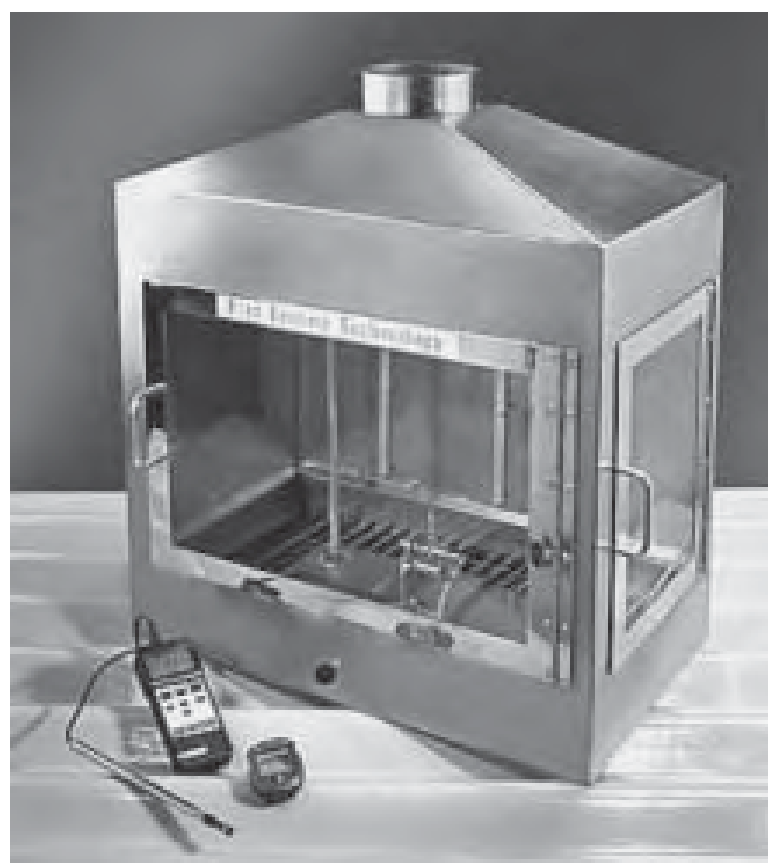

Figure 3 Combustion chamber according to the STN EN 11925-2

Slika 3. Komora za izgaranje prema STN EN 11925-2

by the burner valve. The turner is tilted to $45^{\circ}$ with respect to its vertical axis and moved horizontally until the flame reaches the pre-set contact point with the test specimen.

The timer is switched on at the moment when the flame contacts the test specimen. The flame is applied for $15 \mathrm{~s}$ or $30 \mathrm{~s}$ (according to the user's requirement or depending on the reaction-to-fire class) and then the burner is retracted in a smooth continuous manner.

If the flame application time is $15 \mathrm{~s}$, the total test duration is $20 \mathrm{~s}$, starting at the moment when the flame was first applied. If the flame application time is $30 \mathrm{~s}$, the total test duration is $60 \mathrm{~s}$, starting at the moment when the flame was first applied. In both cases the position of flame application is recorded and during the test interval (i.e. during $20 \mathrm{~s}$ or $60 \mathrm{~s}$ ) it is observed whether the specimen ignition occurs and whether the flame spreads in the vertical direction more than $150 \mathrm{~mm}$ above the flame application point. At the same time the physical behaviour of the specimen is observed.

\section{RESULTS AND DISCUSSION} 3. REZULTATI I RASPRAVA

\subsection{Determined values of the flash-ignition} temperature and spontaneous-ignition temperature

3.1. Vrijednosti flash temperature paljenja i temperature spontanog paljenja

The experiment was carried out according to the procedure required by the standard STN ISO 871 .

Determined values of the flash-ignition temperature and spontaneous-ignition temperature of the tested specimens as well as the flash-ignition and spontaneous-ignition times are presented in Table 2 .

Table 2 clearly shows that by comparison of the flash-ignition temperature (FIT) and spontaneous-igni- 
Table 2 Determined values of the flash-ignition temperature (FIT) and spontaneous-ignition temperature (SIT) and times of flash-ignition and spontaneous-ignition of the spruce wood specimens

Tablica 2. Vrijednosti flash temperature paljenja (FIT) i temperature spontanog zapaljenja (SIT) te vremena flash paljenja i spontanog zapaljenja smrekova drva

\begin{tabular}{|c|c|c|c|c|c|c|}
\hline $\begin{array}{l}\text { Spruce wood } \\
\text { Smrekovina }\end{array}$ & $\begin{array}{c}\text { Volume mass } \\
\text { of dry material } \\
\text { Volumna masa } \\
\text { suhog materija- } \\
\text { la }\end{array}$ & $\begin{array}{l}\text { Volume mass } \\
\text { after condition- } \\
\text { ing } \\
\text { Volumna masa } \\
\text { nakon kondicio- } \\
\text { niranja }\end{array}$ & $\begin{array}{l}\text { Flash-ignition } \\
\text { temperature } \\
\text { Flash tempera- } \\
\text { tura paljenja }\end{array}$ & $\begin{array}{c}\text { Flash-ignition } \\
\text { time } \\
\text { Flash vrijeme } \\
\text { paljenja }\end{array}$ & $\begin{array}{l}\text { Spontaneous- } \\
\text { ignition tem- } \\
\text { perature } \\
\text { Temperatura } \\
\text { spontanog } \\
\text { zapaljenja }\end{array}$ & $\begin{array}{c}\text { Spontaneous- } \\
\text { ignition time } \\
\text { Vrijeme } \\
\text { spontanog } \\
\text { zapaljenja }\end{array}$ \\
\hline & $\mathrm{kg} \cdot \mathrm{m}^{-3}$ & $\mathrm{~kg} \cdot \mathrm{m}^{-3}$ & ${ }^{\circ} \mathrm{C}$ & $\mathrm{s}$ & ${ }^{\circ} \mathrm{C}$ & $\mathrm{s}$ \\
\hline trunk / deblo & 430 & 486 & 370 & 560 & 400 & 550 \\
\hline branch / grana & 440 & 483 & 390 & 420 & 460 & 395 \\
\hline root/korijen & 410 & 452 & 380 & 485 & 440 & 370 \\
\hline
\end{tabular}

tion temperature (SIT) of the spruce tree trunk, branch and root, the lowest values $\left(370\right.$ and $400{ }^{\circ} \mathrm{C}$ ) were determined for specimens prepared from the trunk (those results are comparable with those referred to in Table 1), higher values $\left(380\right.$ and $440^{\circ} \mathrm{C}$ ) of both temperatures were reached by specimens made from the root. The highest temperatures FIT $\left(390{ }^{\circ} \mathrm{C}\right)$ and SIT $(460$ ${ }^{\circ} \mathrm{C}$ ) were observed for the spruce branch specimens.

From the fire prevention point of view, besides temperature, the time also plays a significant role. Table 2 points out the higher variability of results due to reached time values for the flash-ignition that varies from $420 \mathrm{~s}$ for the branch specimens to $485 \mathrm{~s}$ for the root specimens and up to $560 \mathrm{~s}$ for the trunk specimens.

Similar variability can also be seen with the spontaneous-ignition. These values vary in the range from $370 \mathrm{~s}$ for the root specimens, $395 \mathrm{~s}$ for the branch specimens and $550 \mathrm{~s}$ for the trunk specimens. With the higher temperatures, at which the flash-ignition and spontaneous-ignition occur for the branch and root specimens, shorter times were observed of flash-ignition and spontaneous-ignition.
For the Australian pine tree, Delichatsios et al. (2003) recorded the spontaneous-ignition temperature of approximately $478^{\circ} \mathrm{C}$, which is comparable with the temperature reached by the spruce branch specimens $\left(460{ }^{\circ} \mathrm{C}\right)$ in this experiment. Also Hagen et al. (2009) refer to the spontaneous-ignition temperature of 487.9 ${ }^{\circ} \mathrm{C}$ in the case of the Norway Spruce wood specimens not treated by fire retardant, which is also comparable with our results for spruce branch specimens.

\subsection{Determined values of the mass burning rate 3.2. Vrijednosti brzine gorenja}

The variation of mass burning rate depends on changed distance of the tested specimen from the heat source. The results are shown in Figure 4, where the maximum burning rate values as well as the time required for reaching these maximum burning rate values are referred to.

Based on the variation of mass burning rate curves shown in Figure 3, it may be stated that maximum burning rates can be observed within the whole time interval, during which the specimens were exposed to

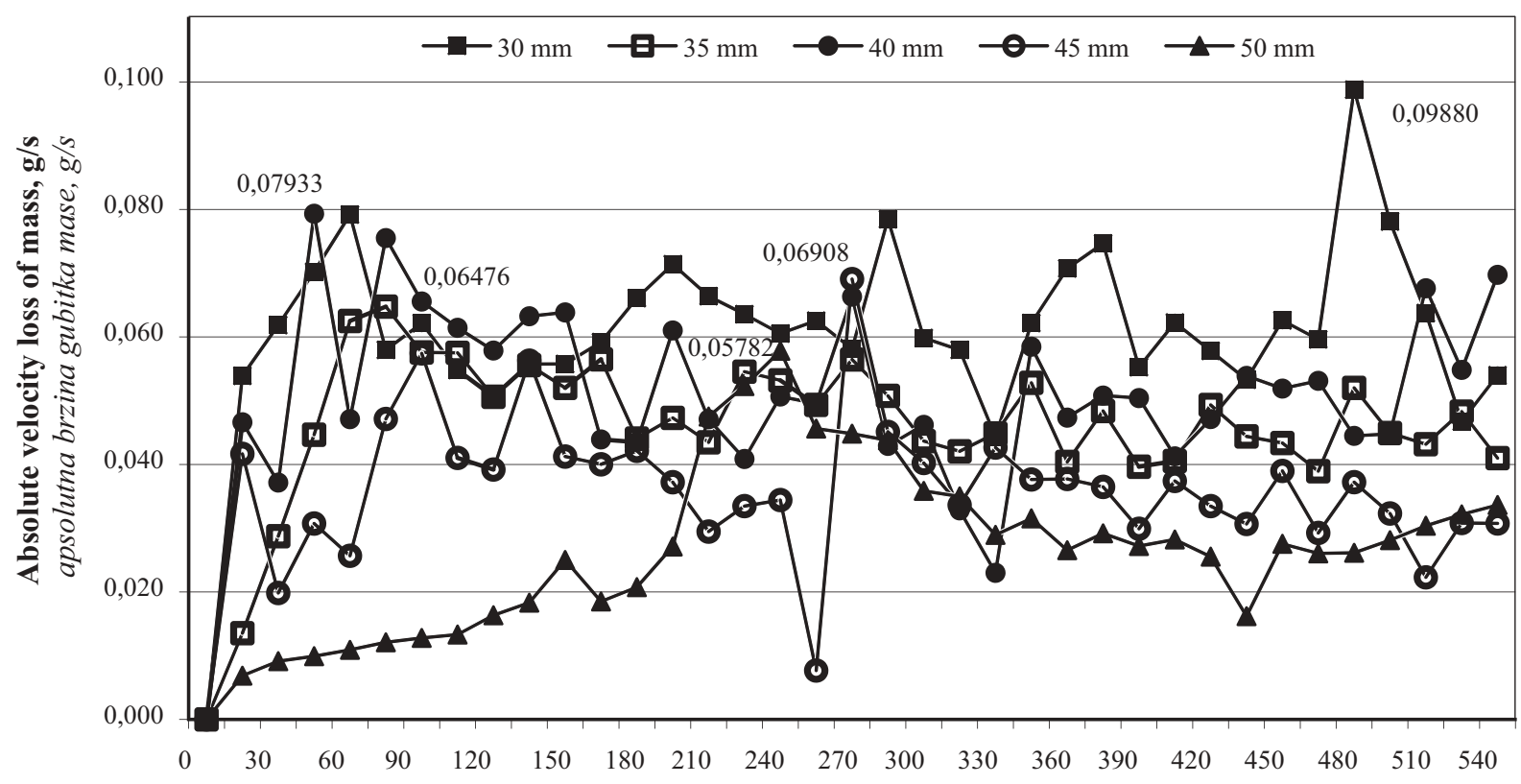

Figure 4 Absolute burning rate of the spruce wood

Time / vrijeme, s

Slika 4. Apsolutna brzina gubitka mase smrekova drva 
Table 3 Values representing burning rate and burning time of the spruce specimens

Tablica 3. Vrijednosti brzine gorenja i vremena gorenja uzoraka od smrekovine

\begin{tabular}{|l|c|c|c|c|c|}
\hline \multirow{2}{*}{ Value / Vrijednost } & \multicolumn{5}{c|}{$\begin{array}{c}\text { Distance between specimen and heat source, } \mathbf{~ m m} \\
\text { Udaljenost izmeđđu uzorka } \text { i izvora topline, mm }\end{array}$} \\
\cline { 2 - 6 } & 30 & 35 & 40 & 45 & 50 \\
\hline $\begin{array}{l}\text { maximum burning rate, } \mathrm{g} \cdot \mathrm{s}^{-1} \\
\text { maksimalna brzina gorenja }, \mathrm{g} \cdot \mathrm{s}^{-1}\end{array}$ & 0.0988 & 0.06476 & 0.07933 & 0.06908 & 0.05782 \\
\hline $\begin{array}{l}\text { time for reaching maximum burning rate, } \mathrm{s} \\
\text { vrijeme postizanja maksimalne brzine gorenja, } \mathrm{s}\end{array}$ & 480 & 75 & 45 & 270 & 240 \\
\hline
\end{tabular}

the thermal loading. The spruce specimens located at the shortest $(30 \mathrm{~cm})$ distance from the heat source reached the highest value of the mass burning rate (in particular in the last test phase), and on the other hand, the specimens located at the furthest distance $(50 \mathrm{~mm})$ from the heat source, reached the lowest maximum burning rate.

Based on the test results, it could be stated that the thermal degradation of material is definitely affected by the distance of the heat source.

The burning speed of spruce wood samples was also introduced in the study by Chrebet et al. (2011), where they used a substantially lower speed of burning. The values varied in the range from 0.0054 to 0.0072 $\mathrm{g} / \mathrm{s}$. Comparing those results with the results of our experiment, it can be concluded that the reason for lower speed values was the difference in the initial phase of sample burning, where it took $26 \mathrm{~s}$ for the samples at a distance of $30 \mathrm{~mm}$ from the source, to start burning.

\subsection{Determined values of ignitability}

3.3 Dobivene vrijednosti zapaljivosti

The experiment was carried out with spruce specimens having dimensions of $250 \times 90 \times 10 \mathrm{~mm}$ carved in a longitudinal direction. The specimens were tested at $30 \mathrm{~s}$ intervals according to the procedure described in the Methods. The flame source was applied in two ways: flame exposure of the front principal area and flame exposure of the lateral side surface (edge) of the specimen. The results are presented in Table 4.

Table 4 shows the differences in ignitability depending on the way of flame exposure to specimens. When the specimens were tested on the surface flame application point (on the front principal area), the ignition occurred in one case only. However, by testing the specimen edge flame exposure (edge flame application point), the ignition occurred in all three cases. These results confirmed the higher ignitability of edges.

Based on this testing, it can be concluded that in no case (neither at the surface flame exposure nor edge flame exposure) the flame height in the vertical direction was higher than $150 \mathrm{~mm}$ during $60 \mathrm{~s}$ (test duration). It means that the criterion $F_{\mathrm{s}} \leq 150 \mathrm{~mm}$ during $60 \mathrm{~s}$ (according to Table 1 in the standard STN EN 13501-1 + A1) for the reaction-to-fire classification into the relevant reaction-to-fire class was fulfilled.

\section{CONCLUSION}

4. ZAKLJUČAK

This paper briefly describes three ways for evaluating fire and burning properties of spruce wood.

It can be stated that every experiment (through its evaluation method) and the results obtained contribute to knowledge in the area of material assessment as regards fire protection, for example:

- The results of the experiment related to the evaluation of the flash-ignition temperature and spontaneous-ignition temperature as well as the times of flash-ignition and spontaneous-ignition of spruce wood showed differences depending on the part of the spruce tree (trunk, branch, root) of which the specimens were made;

- By the evaluation of the mass burning rate, it was established that the value of the maximum burning rate depends on the distance between the tested sample and the initiating heat source;

- The ignitability test showed the difference of ignitability depending on the way of flame exposure to specimens - exposure of the lateral side surface (edge) is more sensitive to ignition than the exposure of the main surface.

Table 4 Evaluation of flame exposure of front (principal) and lateral side surface (edge) of spruce specimens Tablica 4. Procjena izloženosti plamenu prednje strane (osnovice) i bočne strane (ruba) smrekovih uzoraka

\begin{tabular}{|c|c|c|c|c|c|c|}
\hline Flame application point / Točka primjene plamena & \multicolumn{3}{|c|}{ Surface / Površina } & \multicolumn{3}{|c|}{ Edge / $R u b$} \\
\hline Application time / Vrijeme primjene & \multicolumn{3}{|c|}{30 seconds / sekundi } & \multicolumn{3}{|c|}{30 seconds / 30 sekundi } \\
\hline Specimen number / Broj uzorka & 1 & 2 & 3 & 1 & 2 & 3 \\
\hline $\begin{array}{l}\text { Ignition of the specimen (yes/no) } \\
\text { Paljenje uzorka (da/ne) }\end{array}$ & $\begin{array}{l}\text { no } \\
\text { ne }\end{array}$ & $\begin{array}{l}\text { no } \\
\text { ne }\end{array}$ & $\begin{array}{c}\text { yes } \\
\text { da }\end{array}$ & $\begin{array}{c}\text { yes } \\
\text { da }\end{array}$ & $\begin{array}{c}\text { yes } \\
\text { da }\end{array}$ & $\begin{array}{c}\text { yes } \\
\text { da }\end{array}$ \\
\hline Time of ignition, s / Vrijeme zapaljenja, $s$ & - & - & 29 & 26 & 28 & 22 \\
\hline $\begin{array}{l}\text { Flame spreading to } 150 \mathrm{~mm} \text { distance (yes/no) } \\
\text { Širenje plamena na } 150 \mathrm{~mm} \text { udaljenosti (da/ne) }\end{array}$ & $\begin{array}{l}\text { no } \\
\text { ne }\end{array}$ & $\begin{array}{l}\text { no } \\
\text { ne }\end{array}$ & $\begin{array}{l}\text { no } \\
\text { ne }\end{array}$ & $\begin{array}{l}\text { no } \\
\text { ne }\end{array}$ & $\begin{array}{l}\text { no } \\
\text { ne }\end{array}$ & $\begin{array}{l}\text { no } \\
\text { ne }\end{array}$ \\
\hline $\begin{array}{l}\text { Time of flame spreading to } 150 \mathrm{~mm} \text { distance, } \mathrm{s} \\
\text { Vrijeme širenja plamena na udaljenost } 150 \mathrm{~mm}, \mathrm{~s}\end{array}$ & - & - & - & - & - & - \\
\hline
\end{tabular}




\section{Acknowledgments - Zahvala}

The paper was granted by financial support of the Granting Agency of the Ministry of Education of the Slovak Republic VEGA 1/0313/09 and APVV No. SKCN-0006-09.

\section{REFERENCES}

\section{LITERATURA}

1. Delichatsios, M.; Paroz, B.; Bhargava, A., 2003: Flammability properties for charing materials. Fire Safety Journal, 38 (3): 219-228 http://dx.doi.org/10.1016/S0379-7112(02)00080-2.

2. Hagen, M.; Hereid, J.; Delichatsios, M.A.; Zhang, J.; Bakirtzis, D., 2009. Flammability assessment of fire-retarded Nordic Spruce wood using thermogravimetric analyses and cone calorimetry. Fire Safety Journal, 44 (8): 1053-1066 http://dx.doi.org/10.1016/j.firesaf.2009.07.004.

3. Chrebet, T.; Arvajová, Z.; Martinka, J.; Balog, K., 2011: Sledovanie teploty vzplanutia a úbytku hmotnosti v teplovzdušnej elektricky vyhrievanej peci. [Monitoring the temperature of ignition and loss of weight in the air electrically heated furnace]. In POŽÁRNÍ OCHRANA 2011, Sborník prednášek XX. Ročníku konference. VŠB - TU Ostrava, pp. 89 - 91.

4. Kačíková, D.; Netopilová, M.; Osvald, A., 2006: Drevo a jeho termická degradácia. [The wood and its thermal degradation]. In Edice SPBI Spektrum 45. Ostrava : VŠB - TU Ostrava, 2006, 79 p.

5. Karlsson, B.; Quintiere, J. G., 2000: Enclosure fire dynamics. Boca Raton: CRC Press LLC, 2000. 336 p.

6. Korytárová, O.; Osvald, A., 2000. Zmeny v štruktúre vybraných ihličnatých drevín spôsobené vysokými teplotami. [Changes in the structure of selected coniferous wood-trees caused by high temperatures]. In Vedecké štúdie 2/2000/B. Zvolen : ES TU, p. 77.

7. Martinka, J.; Balog, K.; Tureková, I., 2011. Nitrogen oxides production under fire conditions and their impact on the evacuation of people. In: Emergency Evacuation of People from Buildings : International Scientific and Technical Conference. Warsaw, 31.03. - 01.04.2011. - Warsaw: The Main School of Fire Service, 2011, pp. 243-249.

8. Osvald, A.; Komárek, P.; Hubačková, L'., 2007. Hodnotenie vybraných drevín z pohl'adu protipožiarnej ochrany. [Evaluation of selected wood from the fire protection view]. 1. ed. Zvolen: ES TU vo Zvolene, 74 p.
9. Osvald, A.; Osvaldová, L., 2003. Retardácia horenia smrekového dreva. [Retardancy of the spruce wood burning]. In Vedecké śtúdie 3/2003/B. Zvolen : ES TU, 22 p.

10. Požgaj, A.; Chovanec, D.; Kurjatko, S.; Babiak, M., 1997: Štruktúra a vlastnosti dreva. [The structure and properties of wood]. Bratislava: Príroda, $486 \mathrm{p}$.

11. Rowell, R., 2005: Handbook of wood chemistry and wood composites. Publisher: CRC, First edition, New York.

12. Zat'ko, Š., 1993: Vlastnosti tepelných infračervených žiaričov. [Properties of thermal infrared heaters]. In Zborník referátov: Zvolen - mesto drevárskej vedy a praxe. Zvolen: TU vo Zvolene, pp. 375-384.

13. ***1984: Katalóg požiarno-technických vlastností materiálov. Drevo ihličnaté X. [The catalogue of fire and burning behaviour properties of materials. Coniferous wood $X]$. Hlavná správa požiarnej ochrany, Ministerstvo vnútra SSR. [Headquarters Authority for Fire Protection. Ministry of Interior of the Slovak Socialist Republic].

14. ***STN ISO 871: 1999: Plasty. Stanovenie zápalnosti $\mathrm{v}$ teplovzdušnej peci. [Plastics. Determination of ignition temperature using a hot-air furnace]. Slovak Standards Institute - SUTN.

15. ***STN EN ISO 11925-2: 2004: Skúšky reakcie stavebných výrobkov na oheň. Čast' 2: Zapálitel'nost' stavebných výrobkov vystavených pôsobeniu malého plameňa. [Reaction to fire tests - Ignitability of products subjected to direct impingement of flame - Part 2: Single-flame source test]. Slovak Standards Institute - SUTN.

16. ***STN EN 13501-1+A1:2010: Klasifikácia požiarnych charakteristík stavebných výrobkov a prvkov stavieb. Čast' 1: Klasifikácia využívajúca údaje zo skúšok reakcie na oheň. [Fire classification of construction products and building elements. Part 1:Classification using data from reaction to fire tests]. Slovak Standards Institute SUTN.

\section{Corresponding address:}

Ing. MARTIN ZACHAR, Ph.D.

Department of Fire Protection

Faculty of Wood Sciences and Technology

Technical University in Zvolen

T. G. Masaryka 24

96053 Zvolen, SLOVAKIA

E-mail: zachar@vsld.tuzvo.sk 